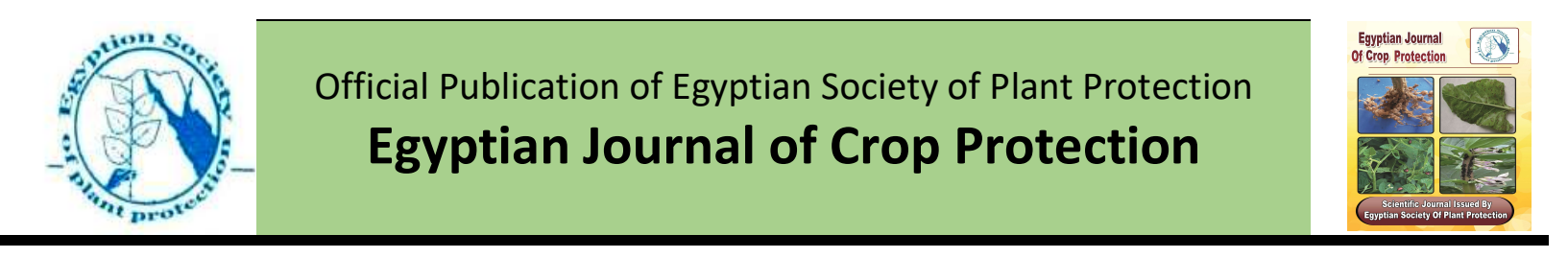

\title{
ECOFRIENDLY MANAGEMENT OF ROOT-KNOT NEMATODES ON EGGPLANT USING COMPOST
}

Mai Nagah Al-Hendy, Ramadan Abdelmoneim Bakr*, Magdy El-Sayed Mahdy and El-Shawadfy Mansour Mousa

Department of Agricultural Botany, Faculty of Agriculture, Menoufia University, Shebin El-Kom, Egypt

\section{ABSTRACT}

Root-knot nematodes (RKN) became a true limited factor for eggplant production worldwide. Experiments were designed to evaluate the effectiveness of different compost types on RKN management in Eggplant under greenhouse conditions. Different compost types i.e. plant, animal, rice straw and maize wood compost at different doses 10, 20, 30, 50 and 100 g/ pot were used. Results indicated that all evaluated treatments showed a great potential in decrease all related nematode parameters i.e. number of galls, egg masses, females/root system and second stage juveniles(J2s)/250g soil compared with control. The most effective treatment in reducing all nematode parameters was animal compost. Results illustrated that all compost types markedly increased eggplant growth parameters. The highest plant growth parameters enhancement obtained when plants treated with animal compost at $10 \mathrm{~g} /$ pot, followed by maize wood compost at the same rate of $10 \mathrm{~g} /$ pot. The lowest plant enhancement recorded with rice straw compost at $100 \mathrm{~g} /$ pot.

Key words: Root-Knot Nematodes, Meloidogyne spp, Compost, Eggplant, Biological Control.

\section{INTRODUCTION}

Recently, Eggplant (Solanum melongena L.) are considered one of the most important economic vegetable crops in Egypt. It is one of the top ten vegetables grown in the world. It is an herbaceous plant that follows family Solanaceae. Nowadays it is widely grown in different seasons throughout the year in opened field and under greenhouse conditions. It contains proportions of dietary fiber, vitamins, and micronutrients. According to the

*Corresponding author email: ramadanbaker82@agr.Menofia.edu.eg (C) Egyptian Society of Plant Protection. report of the Food and Agriculture Organization (FAO,2018), the total cultivated area of eggplant in Egypt reached 46849 ha which yielded 1409202 tons, with an average of $300795 \mathrm{hg} / \mathrm{ha}$. Several diseases were recorded attacking this crop causing several harmful effects. Root-knot nematodes (RKN) Meloidogyne spp. consider one of the most economically important pathogens causing damage and losses of plant growth and yield of 
vegetable crops in Egypt (Bakr et al., $2011,2020)$. High yield loss of eggplant may occur when grown in sandy soils infested with high nematode population, especially in the summer season. International annual loss in eggplant due to nematodes were $16.9 \%$ (Sasser and Freckman,1987). In 2011-2012 the estimated annual yield losses in eggplant due to damage by plant parasitic nematodes in Egypt reached $20 \%$ with 298.41 Million L.E. (Abd-El Gawad, 2014).

Root-knot nematodes are capable of harshly damaging a broad range of crops, causing dramatic yield losses mainly in tropical and subtropical agriculture (Sikora and Fernandez, 2005). Infected plants with RKN almost showed poor growth as a result to reduction of nutrient and water uptake which substantially resulting damage to the root system, and therefore give low yields and quality (Abd-Elgawad,2021). Also, RKN can break the resistance of host plant and make it more susceptible to other pathogens (Castello et al., 2003; Manzanilla- Lopez et al., 2004).

Consequently, Nematologistis all over the world are keeping searching for alternative control methods to avoid the harmful effect of nematicides on plant, animals, environment (Bakr and Ketta, 2018) and ensure high quality free residual products. Compost acts as a food source and shelter for the antagonists that compete with plant pathogens, for those organisms that prey on and parasitize pathogens, for those beneficial that produce antibiotics and for those microorganisms that induce resistance in plants. Compost has a lot of elements like nitrogen, phosphorus and potassium, this material increases salt and soil acidification. Moreover, it contains a high in phosphorous and potassium while relatively low in nitrate nitrogen. It has a very high cation exchange capacity, relatively high levels of soluble salts, a slow mineralization rate, and it is "light in weight yet bulky in volume" (Wuest et al., 1995). Therefore, the present investigation was planned to study some safety alternative methods on controlling root-knot nematodes by using different compost types.

\section{MATERIALS AND METHODS}

\section{Multiplication of Meloidogyne spp.:}

Roo-knot nematodes Meloidogyne spp. multiplied on tomato (Lycopersicon esculentum) CV. Beto86. Infected plants grown in plastic pots $30 \mathrm{~cm}$ in diameter filled with sterilized clay-sand mixed soil (1:2 v/v) under greenhouse conditions at the experimental farm, Faculty of 
Agriculture, Menoufia University, Shebin El-Kom, Egypt.

Preparation of Meloidogyne spp. inoculum:

Three months old tomato roots infected with Meloidogyne spp. were used to prepare nematode inoculum. Tomato infected galled roots were removed from the pots and gently washed with tap water to remove the adherent soil particles. Roots were cut into small pieces and then were macerated for two periods of 10 seconds each at high speed by using a Waring blender Monilinex. The macerated root solution was then placed in a bottle containing sodium hypochlorite $(\mathrm{NaOCl})$ adjusted to the final concentration of $0.5 \%$ to extract nematode eggs as described by Hussey and Barker (1973). The solution in the bottle was vigorously shaken for 3 minutes to release the eggs from the egg matrix as $\mathrm{NaOCl}$ helps in removes the gelatin matrix of egg masses. The solution was then poured through arranged different size sieves to remove the root tissue. Eggs were collected on the 20 micrometer $(\mu \mathrm{m})$ sieve and washed several times with tap water to remove residual $\mathrm{NaOCl}$. Eggs were then transferred to a flask containing tap water then number of eggs $/ 1 \mathrm{ml}$ counted under light microscope.

Effect of different compost types on eggplant plants infected with Meloidogyne spp.

The experiment was carried out under greenhouse conditions at Department of Agricultural Botany, Faculty of Agriculture, Menoufia University, Shebin El-Kom, Egypt to evaluate the effect of different compost types i.e. plant, animal, rice straw and maize wood compost on root-knot nematodes management.

Plastic pots $(15 \mathrm{~cm}$ in diameter) were filled with two $\mathrm{kg}$ of an unsterilized mixed sand / clay soil (2/1 $\mathrm{v} / \mathrm{v})$. Different compost types were mixed with soil pots at $10,20,30,50$ and $100 \mathrm{~g} /$ pot. Soil pots watered daily to allow compost decomposition. One week later, three weeks old eggplant seedlings (Solanum melongena L.) cv. Balady were transplanted in pots (one seedling/pot). Each treatment was replicated three times. Three days later, three thousand (3000) eggs of Meloidogyne spp. as initial population (PI) were inoculated/plant by pipetting into 3-4 holes around the new hairy roots.

Plants watered as needed and weekly fertilized with $5 \mathrm{ml}$ of $2 \mathrm{~g} / \mathrm{l}$ of $\mathrm{N}$ : P: K (20:20:20); manufactured by 
International Egypt company for Agricultural and Industrial Developing.

Sixty days from nematode inoculation plants were uprooted and their roots were carefully washed under running tap water to remove adhesive soil particles. Nematode parameters i.e., number of galls, females and egg masses/ root system as well as $J_{2} \mathrm{~s} / 250 \mathrm{~g}$ soil, were recorded. Egg masses were assessed by staining the root system with Phloxin-B solution ( $0.15 \mathrm{~g} / \mathrm{l}$ tap water) for 20 minutes according to Daykin and Hussey (1985). Females of Meloidogyne spp. were collected using technique described by Mahdy (2002) by cutting the root system of each plant in $2 \mathrm{~cm}$ pieces and submerging the root pieces in a beaker full of tap water for 4 days at room temperature until they became soft. The roots were then washed through 250 and $500 \mu \mathrm{m}$ sieves to separate the females from the root debris then counted.

Nematode population in the soil pot was enumerated by extraction rootknot nematode $\mathrm{J}_{2} \mathrm{~S}$ by using the tray modification of Baermann funnel as described by Barker (1985). The nematode enumeration was done using the stereomicroscope. The rate of nematode reproduction was calculated according to Norton (1978) whereas:

Reproduction Factor $(\mathrm{RF})=$ Final Population (PF)/Initial Population (PI).

Plant growth parameters i.e. plant and shoot lengths $(\mathrm{cm})$, fresh shoot and root weights $(\mathrm{g})$ and dry shoot weight $(\mathrm{g})$ were recorded.

Determination of antioxidant enzymes activity:

\section{A- Peroxidase}

Peroxidase activity was measured according to the method described by Fehrman and Dimond (1967). Ten grams of fresh leaves were ground in a mortar with $10 \mathrm{ml}$ of phosphate buffer $(\mathrm{pH} 6)$ extracts and then centrifuged for $15 \mathrm{~min}$. at $4000 \mathrm{rpm}$. The supernatant was diluted by adding $8 \mathrm{ml}$ distilled water to $2 \mathrm{ml}$ supernatant. The reaction mixture consisted of $1.5 \mathrm{ml}$ of $0.04 \mathrm{M}$ caticol solution, $1.5 \mathrm{ml} \mathrm{H}_{2} \mathrm{O}_{2}, 1.5 \mathrm{ml}$ phosphate buffer $(\mathrm{pH} 6)$ and $1 \mathrm{ml}$ of extract. The control was done similarly except the extract was previously boiled. The difference in optical densities between the reaction mixture and that of the control was taken as a measure of the activity of reaction. Enzymes activity was expressed as the increase in optical density from 60 - 120 seconds after the substrate was added. Aliquots of the supernatant 
were assayed colorimetrically at 470 $\mathrm{nm}$.

\section{B- Phenoloxidase}

Phenoloxidase measured using the method described by Broesh (1954). Ten grams of leaves was ground in mortar with $10 \mathrm{ml}$ borate buffer (pH9). Extracts were centrifuged for $15 \mathrm{~min}$. at $4000 \mathrm{rpm}$. The supernatant was diluted by adding $9 \mathrm{ml}$ distilled water to $2 \mathrm{ml}$ supernatant. The reaction mixture consisted of $2 \mathrm{ml}$ borate buffer $(\mathrm{pH} 9), 1 \mathrm{ml}$ of $1 \%$ para aminobenzoic acid, $2 \mathrm{ml}$ of $1 \%$ caticol and $1 \mathrm{ml}$ extract. Control was done similarly except the extract was previously boiled. Then liquates of the supernatant were measured colorimetrically at 575 $\mathrm{nm}$.

\section{Statistical analysis}

Data were statistically analyzed using analysis of variance (ANOVA) and comparisons of means at the $5 \%$ level of significance using costat 6.3 version program according to Duncan's multiple range test.

\section{RESULTS}

Results showed that all compost treatments significantly reduced the nematode root galling and inhibited the nematode reproduction on eggplant plants. All treatments reduced all related nematode parameters i.e. number of galls, egg masses, females/root system, $\mathrm{J}_{2} \mathrm{~S} / 250$ $g$ soil, final population and reproduction factor compared with control as illustrated in table (1). Results showed that animal compost was the highest effective one in reducing all recorded nematode parameters specially at the low doses(10g), followed by maize wood compost, plant compost and rice straw compost, respectively. The lowest value of nematode reproduction was noticed with animal compost followed by maize wood compost, while the greatest values were found by rice straw compost. Results showed that the lowest number of galls was recorded with the rate of $10 \mathrm{~g} / \mathrm{pot}$ of animal compost, followed by $10 \mathrm{~g} / \mathrm{pot}$ of maize wood compost and the highest number of galls/root system observed with the rate of $100 \mathrm{~g} / \mathrm{pot}$ from rice straw compost. Reduction percentage of galls $98 \%$, followed by maize wood compost $97 \%$ as presented in Fig (1). Results revealed that, there are no significant differences between both of applied doses $10 \mathrm{~g} /$ pot from animal compost and $10 \mathrm{~g} / \mathrm{pot}$ from maize wood compost, but the significant differences showed between doses and the plant treated with nematode 
alone. Results found that the most effective treatment absolutely in reducing root galling was animal compost at the low rate of $10 \mathrm{~g} / \mathrm{pot}$, and the lowest effect recorded with rice straw compost at the rate of 100 g/pot.

Examination of root system cleared that all treatments at all doses decreased the mean number of egg masses/ root system compared to untreated pots. Animal compost, plant compost and maize wood compost showed the high effect in reducing the egg masses, while rice straw compost showed a little effect. Obtained results indicated that the low rate of $10 \mathrm{~g} /$ pot from animal compost, plant compost and maize wood compost present high effect in reducing the number of egg masses /root system. The lowest effect obtained with $100 \mathrm{~g} / \mathrm{pot}$ from animal compost. No significant differences between all applied low rates $10 \mathrm{~g} / \mathrm{pot}$ of all treatments, but significant differences recorded between treatments and plants treated with nematode alone. Reduction percentage of egg masses in plants treated with both of animal and plant compost was reached $98 \%$, followed by maize wood compost by $97 \%$ as shown in Fig (2). Generally, results showed that the highest mean number of egg masses recorded with plant compost at $100 \mathrm{~g} / \mathrm{pot}$, that mean the high doses don't play a role in reducing the egg masses. Results revealed that animal compost, plant compost and maize wood compost at the rate of $10 \mathrm{~g} /$ pot was the best treatment in all amendments doses and the least one rice straw compost alone at $100 \mathrm{~g} /$ pot in inhibiting number of females/ root system. Reduction percentage of females by animal and plant compost was $96 \%$, followed by maize wood compost by $94 \%$ as presented in Fig (3). Results cleared that the number of second stage juveniles markedly affected by all the treatments. Data illustrated that the animal compost at $10 \mathrm{~g} /$ pot was the most effective one in reducing the number of second stage juveniles/ $250 \mathrm{~g}$ soil. The same results recorded with animal compost at $20 \mathrm{~g} /$ pot. The least effective treatment was maize wood compost at $100 \mathrm{~g} /$ pot. Reduction percentage of second stage juveniles by animal and plant compost reached $97 \%$, whereas the least effective treatment was animal and maize wood compost by $80 \%$ as illustrated in Fig (4). 
Table (1): Effect of different compost types at different doses on eggplant plants infected with root-knot nematodes under greenhouse conditions.

\begin{tabular}{|c|c|c|c|c|c|c|c|}
\hline \multirow[t]{2}{*}{ Treatment } & \multirow[t]{2}{*}{$\begin{array}{l}\text { Doses } \\
\text { g/kg soil }\end{array}$} & \multirow{2}{*}{ Second stage $/ 250 \mathrm{~g}$} & \multicolumn{3}{|c|}{$\begin{array}{c}\text { Nematode parameters/ root } \\
\text { system }\end{array}$} & \multirow[t]{2}{*}{$\begin{array}{c}\text { Final } \\
\text { Population (PF) }\end{array}$} & \multirow[t]{2}{*}{$\begin{array}{l}\text { Reproduction } \\
\text { Factor (RF) }\end{array}$} \\
\hline & & & Galls & Egg masses & Females & & \\
\hline \multirow[t]{4}{*}{ Plant compost } & 10 & $66.66^{c}$ & $2.0^{\mathrm{hij}}$ & $0.66^{\mathrm{k}}$ & $1.66^{1}$ & 70.98 & 0.023 \\
\hline & 20 & $133.3^{\mathrm{c}}$ & $6.66^{\text {fghij }}$ & $6.66^{\text {hijk }}$ & $7.66^{\mathrm{ijkl}}$ & 154.31 & 0.05 \\
\hline & 30 & $133.3^{c}$ & $10.33^{\mathrm{efg}}$ & $8.66^{\text {ghij }}$ & $9.66^{\text {hijk }}$ & 161.98 & 0.05 \\
\hline & 50 & $200.0^{\mathrm{bc}}$ & $14.33^{\mathrm{de}}$ & $11.3^{\text {efgh }}$ & $12.6^{\text {efghi }}$ & 238.32 & 0.07 \\
\hline Nematode & 100 & $266.6^{\mathrm{bc}}$ & $14.33^{\mathrm{de}}$ & $22.3^{b c}$ & $25.0^{\mathrm{bc}}$ & 328.32 & 0.1 \\
\hline \multirow[t]{2}{*}{ Animal compost } & 10 & $66.66^{\mathrm{c}}$ & $1.0^{\mathrm{j}}$ & $0.66^{\mathrm{k}}$ & $1.66^{1}$ & 69.98 & 0.02 \\
\hline & 20 & $66.66^{\mathrm{c}}$ & $5.33^{\text {ghij }}$ & $2.66^{\mathrm{jk}}$ & $3.33^{\mathrm{kl}}$ & 77.98 & 0.02 \\
\hline \multirow[t]{2}{*}{+} & 30 & $133.3^{\mathrm{c}}$ & $7.0^{\text {fghi }}$ & $3.33^{\mathrm{ijk}}$ & $4.33^{\mathrm{jkl}}$ & 147.99 & 0.04 \\
\hline & 50 & $533.3^{b}$ & $18.6^{\mathrm{cd}}$ & $16.3^{\text {cde }}$ & $18.6^{\text {cde }}$ & 586.98 & 0.19 \\
\hline Nematode & 100 & $533.3^{b}$ & $20.0^{\mathrm{cd}}$ & $18.6^{\mathrm{cd}}$ & $21.3^{\mathrm{bcd}}$ & 593.32 & 0.19 \\
\hline \multirow[t]{2}{*}{ Rice straw compost } & 10 & $133.33^{\mathrm{c}}$ & $7.33^{\text {fgh }}$ & $5.33^{\text {hijk }}$ & $8.0^{\mathrm{ijkl}}$ & 153.99 & 0.05 \\
\hline & 20 & $133.33^{c}$ & $12.0^{\mathrm{ef}}$ & $9.66^{\text {fghi }}$ & $11.0^{\text {fghi }}$ & 165.99 & 0.05 \\
\hline+ & 30 & $133.33^{\mathrm{c}}$ & $18.0^{\mathrm{cd}}$ & $14.3^{\text {defg }}$ & $15.0^{\text {defgh }}$ & 180.66 & 0.06 \\
\hline Nematode & 100 & $266.66^{\mathrm{bc}}$ & $28.3^{\mathrm{b}}$ & $25.0^{\mathrm{b}}$ & $26.6^{\mathrm{b}}$ & 346.65 & 0.1 \\
\hline \multirow[t]{2}{*}{ Maize wood Compost } & 10 & $133.3^{\mathrm{c}}$ & $1.33^{\mathrm{ij}}$ & $1.33^{\mathrm{k}}$ & $2.66^{1}$ & 138.65 & 0.04 \\
\hline & 20 & $200.0^{\mathrm{bc}}$ & $8.0^{\mathrm{fg}}$ & $6.66^{\text {hijk }}$ & $8.0^{\mathrm{ijkl}}$ & 222.66 & 0.07 \\
\hline+ & 30 & $200.0^{\mathrm{bc}}$ & $10.3^{\text {efg }}$ & $8.66^{\text {ghij }}$ & $10.0^{\text {ghij }}$ & 228.99 & 0.07 \\
\hline \multirow[b]{2}{*}{ Nematode } & 50 & $266.6^{\mathrm{bc}}$ & $21.0^{c}$ & $15.0^{\text {defg }}$ & $16.3^{\text {defg }}$ & 318.99 & 0.1 \\
\hline & 100 & $533.3^{b}$ & $21.0^{\mathrm{c}}$ & $15.66^{\text {def }}$ & $17.0^{\text {def }}$ & 586.99 & 0.19 \\
\hline \multicolumn{2}{|c|}{ Nematode alone } & $2666.66^{\mathrm{a}}$ & $52.66^{\mathrm{a}}$ & $49^{\mathrm{a}}$ & $50.33^{\mathrm{a}}$ & 5024.74 & 1.75 \\
\hline
\end{tabular}

Columns followed by different letters are significantly different according to Duncan's Multiple Test $(P \leq 0.0)$. 
Data extracted after calculation of final population showed that $10 \mathrm{~g} /$ pot of animal compost recorded the highest effective treatment, followed by $20 \mathrm{~g} /$ pot from animal compost in reducing final population as presented in fig (5). In the same manner, results illustrated that animal compost at $10 \mathrm{~g} /$ pot also the most effective one in reducing the reproduction factor. The same results recorded with $20 \mathrm{~g} /$ pot of animal compost as illustrated in fig (6).

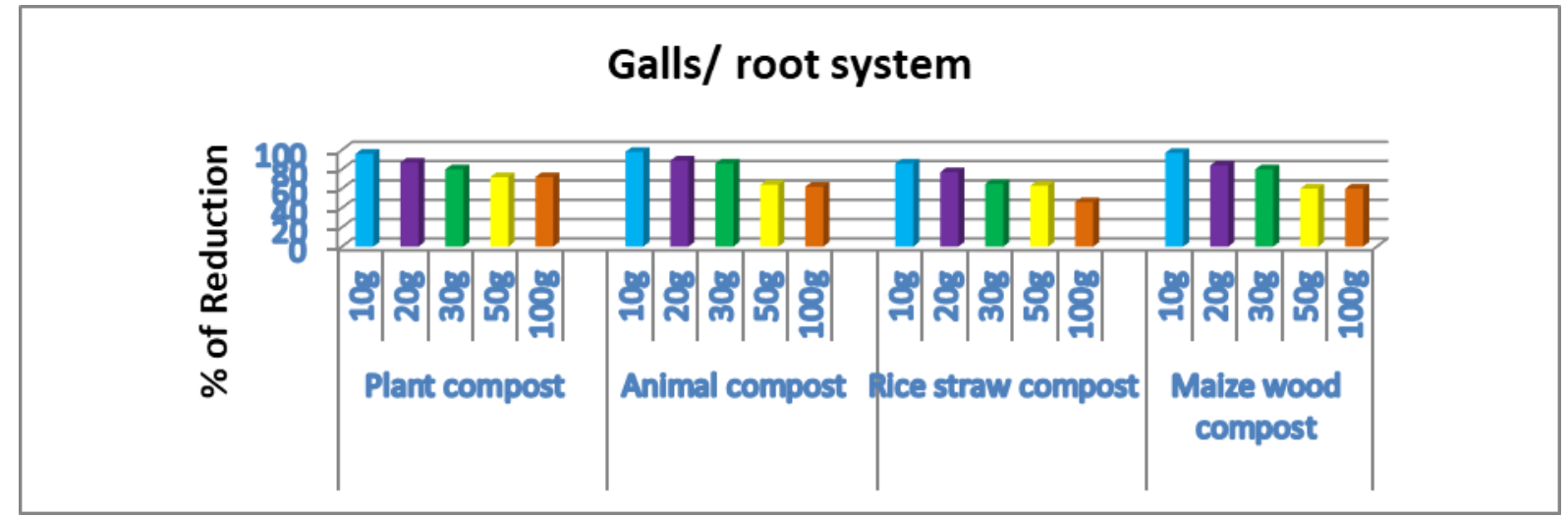

Fig (1): Effect of different compost types at different doses on reduction percentage of galls/ root system.

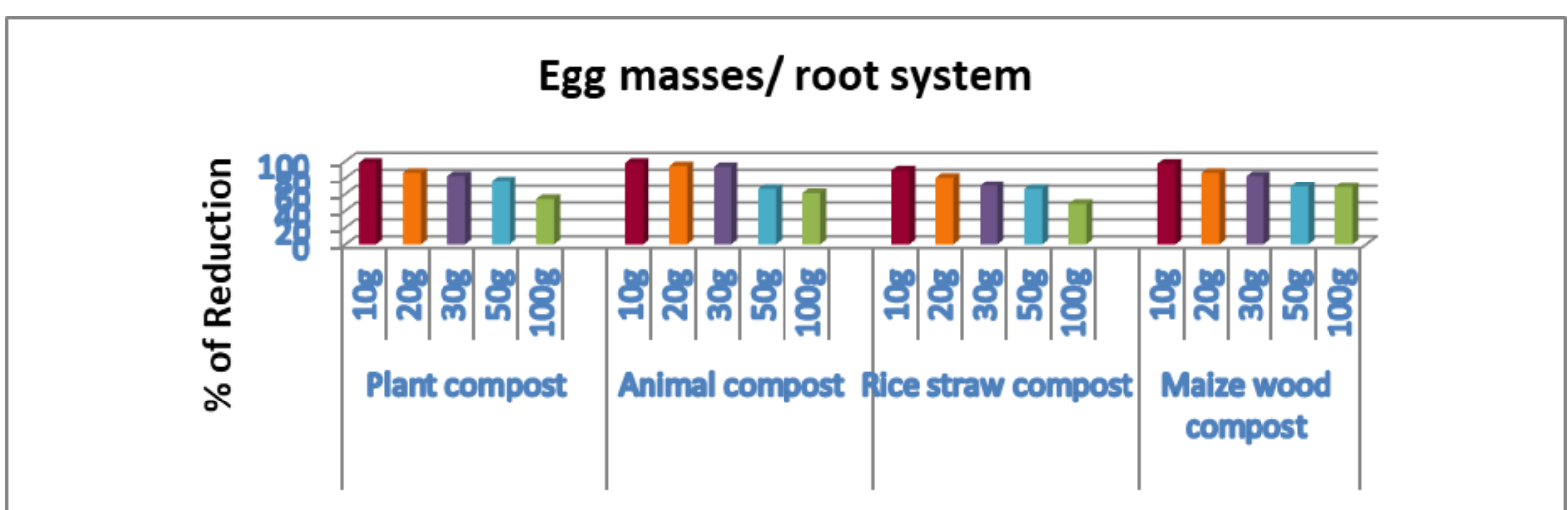

Fig (2): Effect of different compost types at different doses on reduction percentage of egg masses/ root system.

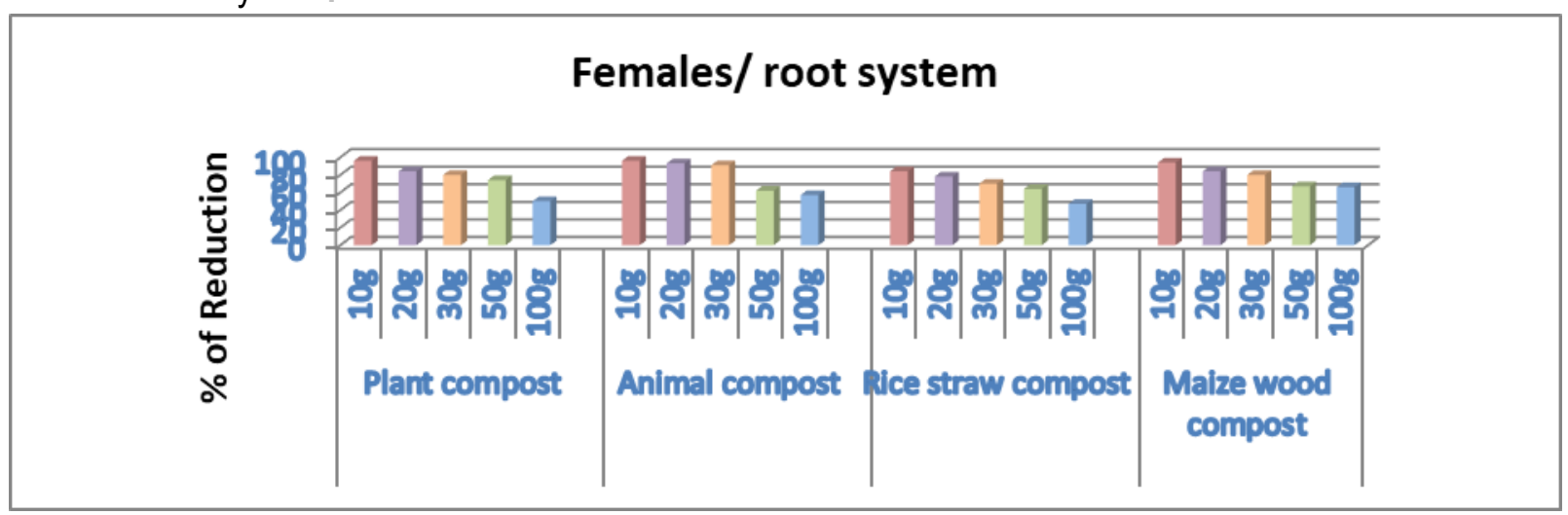

Fig (3): Effect of different compost types at different doses on reduction percentage of females/ root system. 


\section{Second stage juveniles/ $250 \mathrm{~g}$ soil}

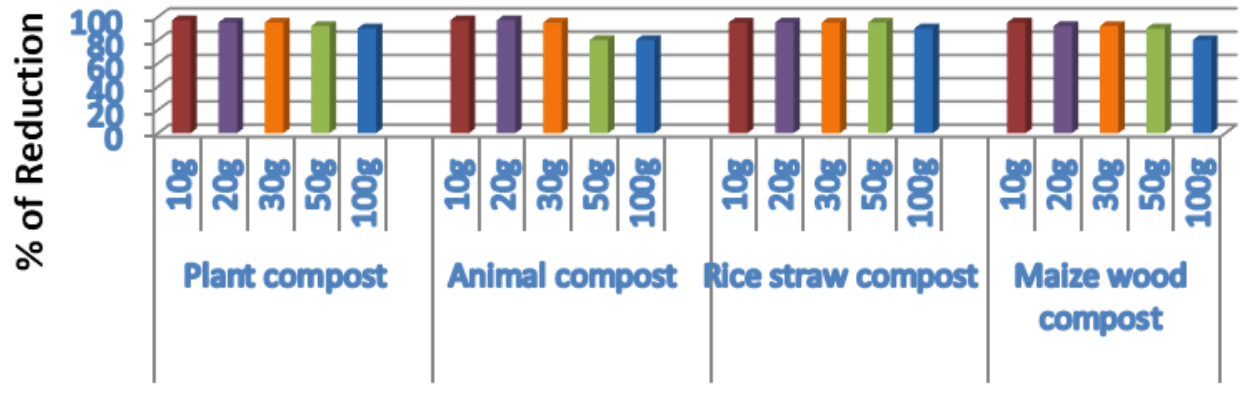

Fig (4): Effect of different compost types at different doses on reduction percentage of second stage juveniles/ $250 \mathrm{~g}$ soil.

\section{Final population (Pf)}

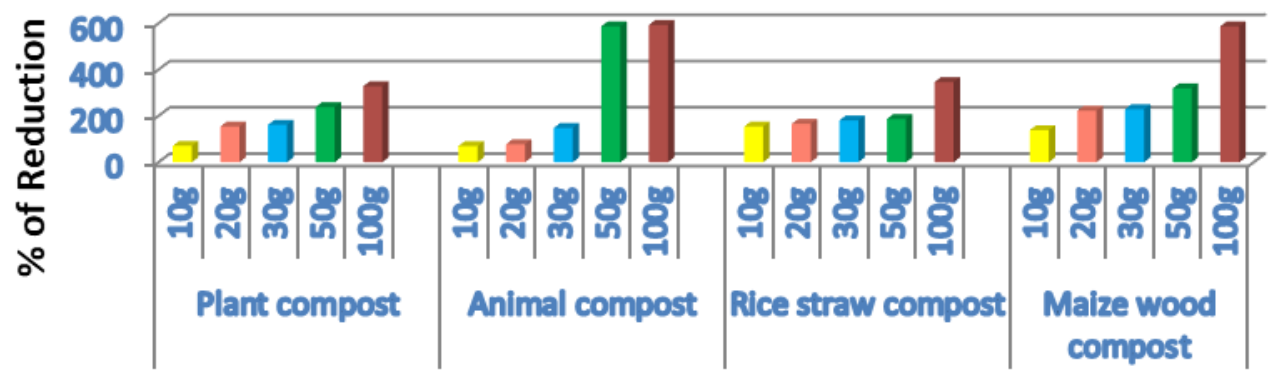

Fig (5): Effect of different compost types at different doses on reduction percentage of nematode final population.

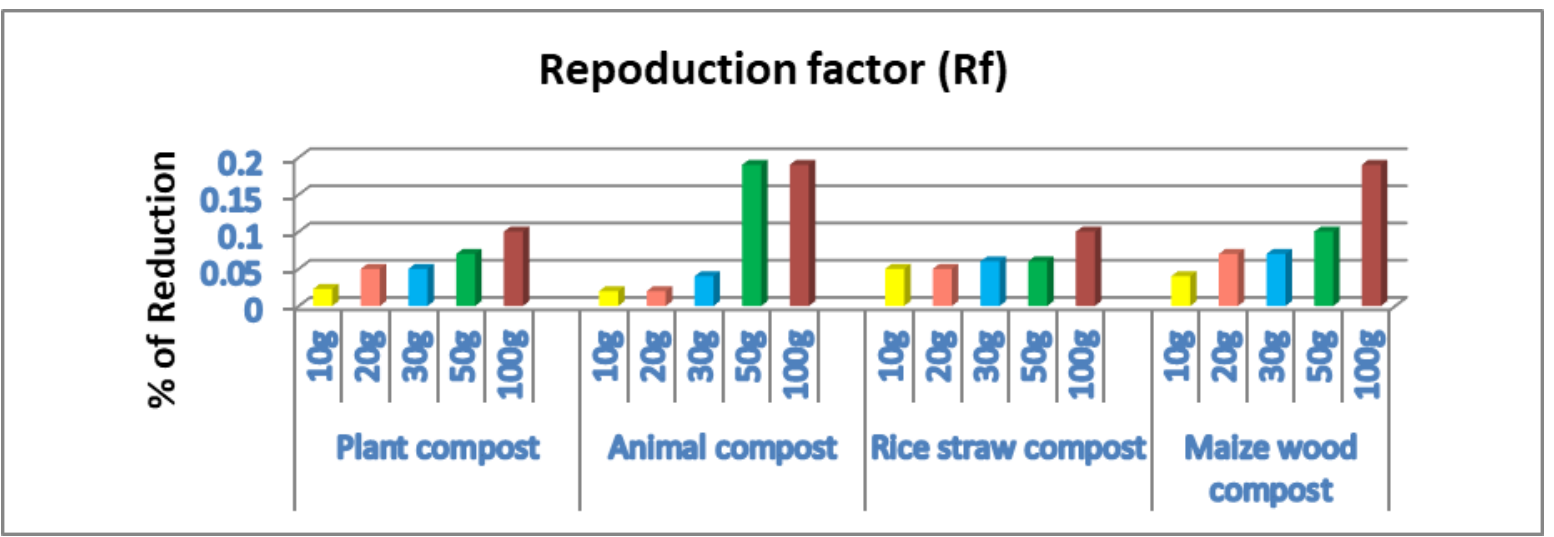

Fig (6): Effect of different compost types at different doses on reduction percentage of reproduction factor.

Results presented in table (2) showed that all treatments of different compost types affected the plant growth parameters of eggplant infected with RKN under greenhouse conditions. Data revealed that the highest plant length was obtained when plants treated with animal compost at 10g/ pot, followed by maize wood compost at the rate of $10 \mathrm{~g} / \mathrm{pot}$. 
Table (2): Effect of different compost types at different doses on growth parameters of eggplant plants infected with root-knot nematodes under greenhouse conditions.

\begin{tabular}{|c|c|c|c|c|c|c|c|c|c|c|c|}
\hline Treatment & 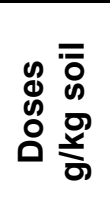 & $\begin{array}{c}\text { Plant } \\
\text { Length } \\
\text { (cm) }\end{array}$ & 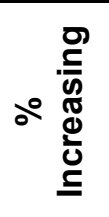 & $\begin{array}{c}\text { Shoot } \\
\text { Length } \\
\text { (cm) }\end{array}$ & ○̊ & $\begin{array}{c}\text { Fresh } \\
\text { shoot } \\
\text { Weight } \\
\text { (g) }\end{array}$ & ○े & $\begin{array}{c}\text { Fresh } \\
\text { Root } \\
\text { Weight } \\
\text { (g) }\end{array}$ & 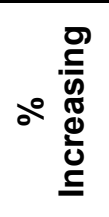 & $\begin{array}{c}\text { Dry } \\
\text { shoot } \\
\text { Weight } \\
\text { (g) }\end{array}$ & 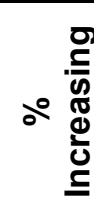 \\
\hline \multirow{5}{*}{$\begin{array}{c}\text { Plant } \\
\text { compost } \\
\mathbf{+} \\
\text { Nematode }\end{array}$} & 10 & $34.0^{\text {de }}$ & 85 & $29.0^{\mathrm{b}}$ & 117 & $11.4^{\mathrm{bc}}$ & 315 & $2.82^{b}$ & 984 & $4.06^{\text {bcde }}$ & 272 \\
\hline & 20 & $30.6^{\mathrm{fg}}$ & 67 & $25.3^{b}$ & 90 & $5.82^{\mathrm{fg}}$ & 111 & $1.56^{\text {cdef }}$ & 500 & $3.22^{\text {defg }}$ & 195 \\
\hline & 30 & $29.0^{\text {fghi }}$ & 58 & $23.6^{\mathrm{b}}$ & 77 & $5.55^{\mathrm{fg}}$ & 101 & $1.41^{\text {cdef }}$ & 442 & $3.10^{\text {defg }}$ & 184 \\
\hline & 50 & $27.6^{\text {hij }}$ & 50 & $22.0^{\mathrm{b}}$ & 65 & $4.52^{g h i}$ & 64 & $1.73^{\text {cdefg }}$ & 426 & $2.15^{\text {fghi }}$ & 97 \\
\hline & 100 & $25.3^{j \mathrm{k}}$ & 38 & $20.3^{b}$ & 52 & $4.25^{\mathrm{ghi}}$ & 54 & $0.91^{\mathrm{fgh}}$ & 250 & $1.63^{\mathrm{hi}}$ & 49 \\
\hline \multirow{5}{*}{$\begin{array}{c}\text { Animal } \\
\text { compost } \\
+ \\
\text { Nematode }\end{array}$} & 10 & $40.0^{a}$ & 118 & $41.0^{\mathrm{a}}$ & 207 & $14.6^{a}$ & 432 & $4.73^{a}$ & 1719 & $5.63^{a}$ & 416 \\
\hline & 20 & $37.0^{\mathrm{bc}}$ & 101 & $34.3^{b}$ & 157 & $12.8^{\mathrm{ab}}$ & 365 & $1.99^{c}$ & 665 & $3.86^{\text {cde }}$ & 254 \\
\hline & 30 & $34.0^{\text {de }}$ & 85 & $32.3^{b}$ & 142 & $8.67^{\mathrm{de}}$ & 215 & $1.65^{\text {cde }}$ & 534 & $3.40^{\text {cdef }}$ & 211 \\
\hline & 50 & $30.3^{\text {fgh }}$ & 65 & $29.0^{b}$ & 117 & $8.25^{\mathrm{de}}$ & 200 & $1.52^{\text {cdef }}$ & 484 & $2.16^{\mathrm{fghi}}$ & 98 \\
\hline & 100 & $26.3^{\mathrm{ijk}}$ & 43 & $26.3^{b}$ & 97 & $7.35^{\text {ef }}$ & 167 & $1.01^{\text {efg }}$ & 288 & $1.56^{\mathrm{hi}}$ & 43 \\
\hline \multirow{5}{*}{$\begin{array}{c}\text { Rice straw } \\
\text { compost } \\
+ \\
\text { Nematode }\end{array}$} & 10 & $31.66^{\mathrm{ef}}$ & 72 & $26.66^{b}$ & 100 & $9.16^{\mathrm{de}}$ & 233 & $1.96^{c}$ & 653 & $4.63^{\mathrm{abc}}$ & 324 \\
\hline & 20 & $28.66^{\mathrm{ghi}}$ & 56 & $24.0^{b}$ & 80 & $5.09^{g h}$ & 85 & $1.23^{\text {defg }}$ & 373 & $2.07^{\mathrm{ghi}}$ & 89 \\
\hline & 30 & $26.33^{\mathrm{ijk}}$ & 43 & $21.33^{b}$ & 60 & $3.81^{\text {ghi }}$ & 38 & $1.18^{\text {defg }}$ & 353 & $0.93^{i}$ & 64 \\
\hline & 50 & $24.33^{k}$ & 32 & $19.0^{\mathrm{b}}$ & 42 & $3.33^{\mathrm{hi}}$ & 21 & $1.14^{\text {defg }}$ & 338 & $1.33^{i}$ & 22 \\
\hline & 100 & $23.66^{\mathrm{k}}$ & 29 & $19.0^{\mathrm{b}}$ & 42 & $2.93^{i}$ & 6 & $0.86^{\text {fgh }}$ & 230 & $1.26^{\mathrm{i}}$ & 15 \\
\hline \multirow{5}{*}{$\begin{array}{c}\text { Maize wood } \\
\text { compost } \\
+ \\
\text { Nematode }\end{array}$} & 10 & $39.66^{\mathrm{ab}}$ & 116 & $34.33^{b}$ & 157 & $14.51^{\mathrm{a}}$ & 427 & $3.43^{\mathrm{a}}$ & 1219 & $5.26^{\mathrm{ab}}$ & 382 \\
\hline & 20 & $36.33^{\text {cd }}$ & 98 & $30.33^{b}$ & 127 & $10.03^{\text {cd }}$ & 264 & $1.74^{\mathrm{cd}}$ & 569 & $4.30^{\mathrm{bcd}}$ & 294 \\
\hline & 30 & $35.33^{\mathrm{cd}}$ & 92 & $30.0^{\mathrm{b}}$ & 125 & $9.21^{\text {de }}$ & 234 & $1.48^{\text {cdef }}$ & 469 & $3.87^{\text {cde }}$ & 255 \\
\hline & 50 & $34.66^{\mathrm{cd}}$ & 89 & $29.66^{b}$ & 122 & $8.99^{\mathrm{de}}$ & 226 & $1.16^{\text {defg }}$ & 346 & $2.83^{\text {efgh }}$ & 159 \\
\hline & 100 & $29^{\text {fghi }}$ & 58 & $23.33^{b}$ & 57 & $5.77^{\mathrm{fg}}$ & 109 & $0.66^{\text {gh }}$ & 153 & $2.03^{\text {ghi }}$ & 86 \\
\hline \multicolumn{2}{|c|}{ Nematode alone } & $18.33^{\prime}$ & & $13.33^{b}$ & & $2.75^{i}$ & & $0.26^{\mathrm{h}}$ & & $1.09^{i}$ & \\
\hline
\end{tabular}

Columns followed by different letters are significantly different according to Dun can's Multiple Test ( $\mathrm{P} \leq 0.05)$. 
The lowest plant length recorded with rice straw compost at $100 \mathrm{~g} /$ pot. Animal compost at the rate of $10 \mathrm{~g} / \mathrm{pot}$ was the effective one in enhancing plant length as shown in fig (7). Data revealed that the highest shoot length was obtained when plants treated with animal compost followed by maize wood compost regardless of the used doses. The lowest shoot length recorded when plants treated with rice straw compost. The lowest effect recorded with $100 \mathrm{~g} /$ pot. Animal compost at rate of $10 \mathrm{~g} /$ pot was the effective one in enhancing shoot length as shown in fig (8). Data confirmed that the highest fresh shoot weight of eggplant plants recorded with animal compost, followed by plant compost and the least value recorded with rice straw compost. The best doses observed with $10 \mathrm{~g} /$ pot, followed by $20 \mathrm{~g} /$ pot. The least value of fresh shoot weight recorded with $100 \mathrm{~g} /$ pot from rice straw compost. Generally, the best treatment absolutely was animal and maize wood compost at the rate of $10 \mathrm{~g} / \mathrm{pot}$, whereas the lowest treatment was rice straw compost at $100 \mathrm{~g} /$ pot as shown in fig (9). Animal compost recorded the highest fresh root weight regardless of used rates, followed by maize wood compost. The lowest value observed with rice straw compost. Treating plants with $10 \mathrm{~g} /$ pot from animal and maize wood compost recorded highest increase in fresh root weight, followed by $20 \mathrm{~g} /$ pot as presented in fig (10). The best treatment animal compost when applied at $10 \mathrm{~g} /$ pot and the least effective one rice straw compost at $100 \mathrm{~g} /$ pot. Data revealed that the highest dry shoot weight obtained when plants treated with animal compost followed by maize wood compost regardless of doses used. The lowest dry shoot weight recorded when plants treated with rice straw compost at $100 \mathrm{~g} /$ pot. animal compost at rate of $10 \mathrm{~g} /$ pot the effective one in enhancing dry shoot weight as shown in fig (11).

Data presented in table (3) noticed that antioxidant enzymes activity i.e. peroxidase and phenoloxidase were affected by different types of compost application in nematode infected plants compared to plants treated with nematode alone. Data showed that, the highly significant increase in peroxidase and phenoloxidase activities obtained with animal compost, maize wood compost, followed by plant compost. Rice straw compost was the lowest effective one. 


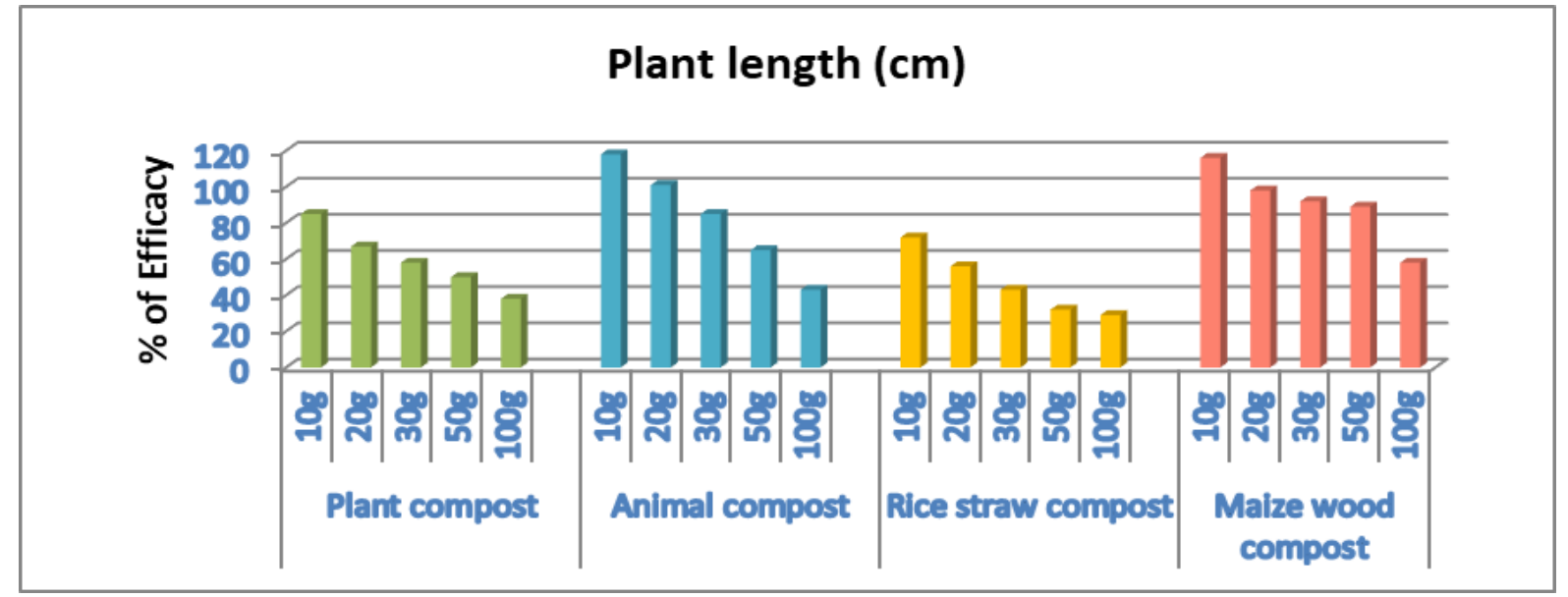

Fig(7): Effect of different compost types at different doses on the plant length of eggplant plants infected with Meloidogyne spp. under greenhouse conditions.

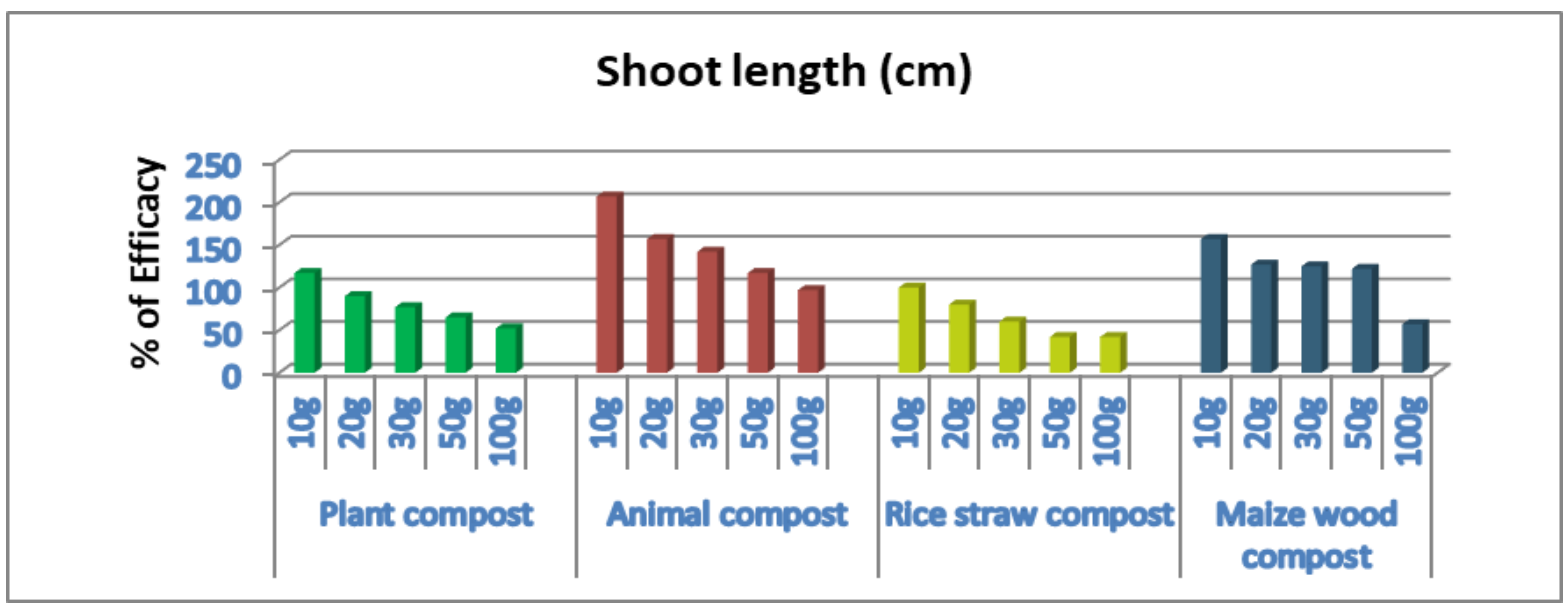

Fig (8): Effect of different compost types at different doses on the shoot length of eggplant plants infected with Meloidogyne spp. under greenhouse conditions.

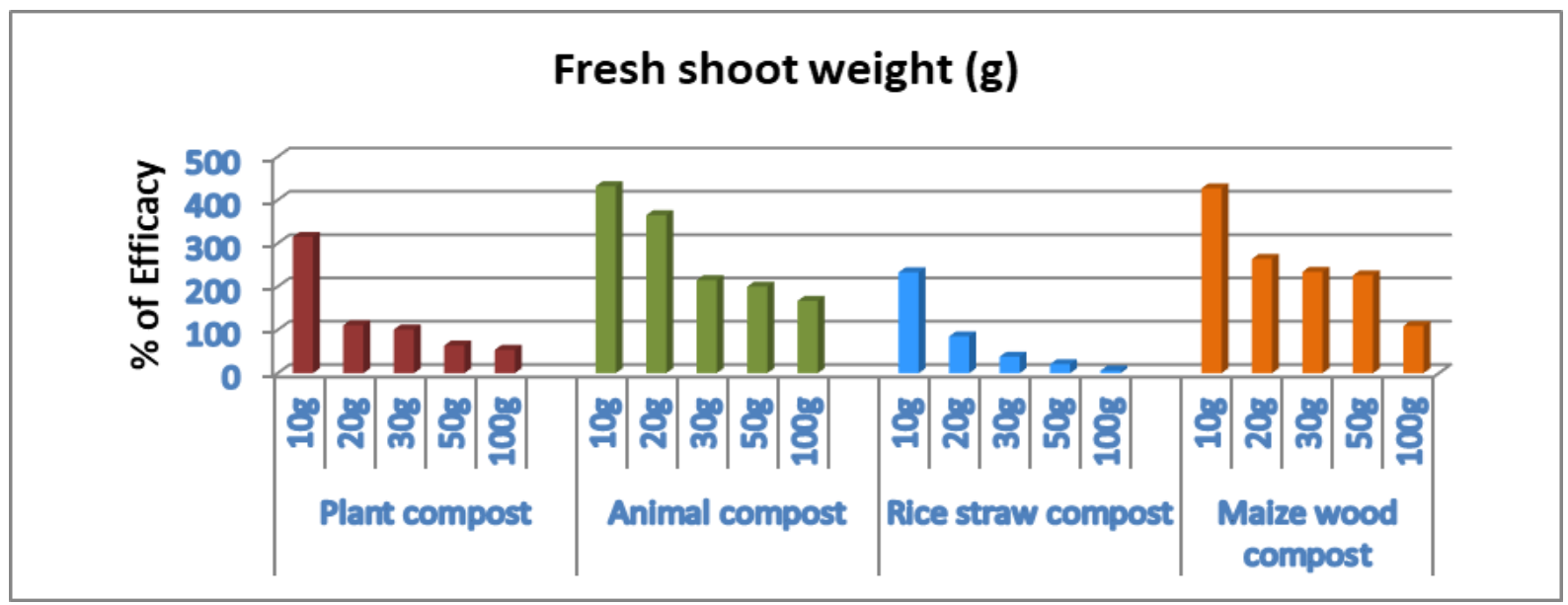

Fig(9): Effect of different compost types at different doses on the fresh shoot weight of eggplant plants infected with Meloidogyne spp. under greenhouse conditions. 


\section{Fresh root weight (g)}

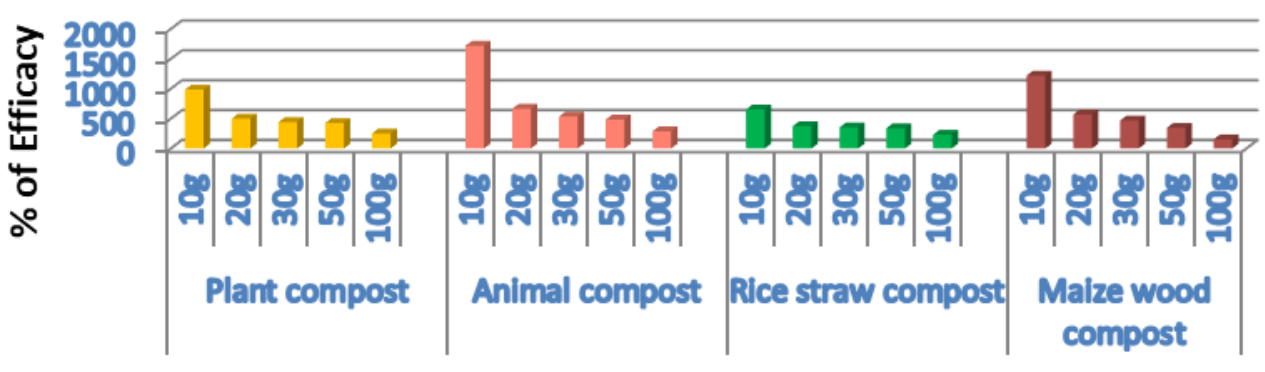

Fig(10): Effect of different compost types at different doses on the fresh root weight of eggplant plants infected with Meloidogyne spp. under greenhouse conditions.

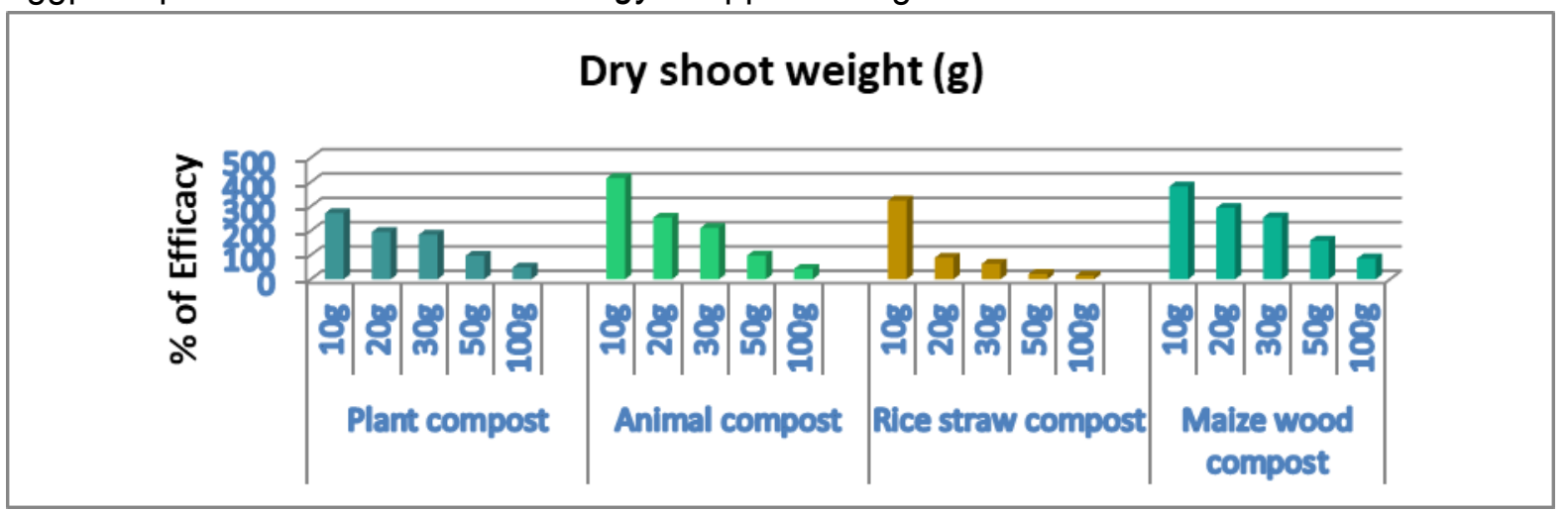

Fig (11): Effect of different compost types at different doses on the dry shoot weight of eggplant plants infected with Meloidogyne spp. under greenhouse conditions.

Table (3): Effect of different compost types at different doses on some antioxidant enzymes activity on eggplant plants infected with Meloidogyne spp.

\begin{tabular}{|c|c|c|c|}
\hline \multirow[b]{2}{*}{ Treatment } & \multirow{2}{*}{$\begin{array}{l}\text { Doses } \\
\text { g/kg soil }\end{array}$} & \multicolumn{2}{|c|}{ Antioxidant enzymes } \\
\hline & & $\begin{array}{l}\text { Peroxidase (O.D.g-1 fr.wt. } \\
\text { after } 2 \mathrm{~min})\end{array}$ & $\begin{array}{l}\text { Phenoloxidase (O.D.g-1 fr.wt. } \\
\text { after } 45 \mathrm{~min} \text { ) }\end{array}$ \\
\hline \multirow{5}{*}{$\begin{array}{c}\text { Plant compost } \\
+ \\
\text { Nematode }\end{array}$} & 10 & $1.20 \mathrm{a}$ & $1.60 \mathrm{a}$ \\
\hline & 20 & $0.80 \mathrm{~b}$ & $0.53 \mathrm{cde}$ \\
\hline & 30 & $0.56 \mathrm{~b}$ & $0.50 \mathrm{cde}$ \\
\hline & 50 & $0.43 \mathrm{~b}$ & $0.46 \mathrm{de}$ \\
\hline & 100 & $0.36 \mathrm{~b}$ & $0.30 \mathrm{de}$ \\
\hline \multirow{5}{*}{$\begin{array}{c}\text { Animal compost } \\
+ \\
\text { Nematode }\end{array}$} & 10 & $1.60 \mathrm{a}$ & $1.06 \mathrm{a}$ \\
\hline & 20 & $0.63 \mathrm{~b}$ & $0.60 \mathrm{bcde}$ \\
\hline & 30 & $0.54 \mathrm{~b}$ & $0.33 \mathrm{de}$ \\
\hline & 50 & $0.53 \mathrm{~b}$ & $0.26 \mathrm{e}$ \\
\hline & 100 & $0.40 \mathrm{~b}$ & $0.23 \mathrm{e}$ \\
\hline \multirow{5}{*}{$\begin{array}{c}\text { Rice straw compost } \\
+ \\
\text { Nematode }\end{array}$} & 10 & $0.93 b$ & $0.63 \mathrm{bcde}$ \\
\hline & 20 & $0.43 b$ & $0.60 \mathrm{bcde}$ \\
\hline & 30 & $0.40 \mathrm{~b}$ & $0.50 \mathrm{cde}$ \\
\hline & 50 & $0.25 \mathrm{~b}$ & $0.36 \mathrm{de}$ \\
\hline & 100 & $0.21 \mathrm{~b}$ & $0.21 \mathrm{e}$ \\
\hline \multirow{5}{*}{$\begin{array}{c}\text { Maize wood compost } \\
+ \\
\text { Nematode }\end{array}$} & 10 & $0.93 b$ & $0.96 \mathrm{bc}$ \\
\hline & 20 & $0.36 \mathrm{~b}$ & $0.73 \mathrm{bcd}$ \\
\hline & 30 & $0.33 \mathrm{~b}$ & $0.63 \mathrm{bcde}$ \\
\hline & 50 & $0.20 \mathrm{~b}$ & $0.33 \mathrm{de}$ \\
\hline & 100 & $0.10 \mathrm{~b}$ & $0.33 \mathrm{de}$ \\
\hline \multicolumn{2}{|l|}{ Nematode alone } & $0.20 \mathrm{~b}$ & $0.17 \mathrm{e}$ \\
\hline
\end{tabular}

Columns followed by different letters are significantly different according to Duncan's Multiple Test $(P \leq 0.05)$ 


\section{DISCUSSION}

There are many previous studies indicated the efficacy of organic and composted materials in reducing and managing different plant pathogens such as bacteria, fungi and Phytonematodes (D'Addabbo et al., 2011; Devi et al.,2020). Numerous studies by researchers worldwide also showed that organic amendments of soil are a means of the nematode control (Arancon et al., 2003; Nahar et al., 2006; Renčo et al., 2007 and Bakr 2017). The efficacy of organic amendments in nematode suppression depends on the $\mathrm{C}$ : $\mathrm{N}$ ratio and a time of microbial decomposition of organic matter (Rodriguez-Kabana et al., 1995; D'Addabbo and Sasanelli, 1997; Akhtar and Malik, 2000). The changed in the $\mathrm{C}: \mathrm{N}$ ratio in organic treatments observed when more nitrogen sources were available, which help in nematode control (Kirmani et al., 1975). Previews studies revealed that materials with lower $\mathrm{C}: \mathrm{N}$ ratios are more nematicidal than those with higher ratios (Kirmani et al. 1975; Ismail et al. 2006; Renčo et al. 2011). The composts release different compounds may be toxic to plant nematodes like phenols, tannins, terpens, (Mian and Rodriguez-Kabana, 1982) or derived during or from decomposition processes in the soil such as: ammonia, nitrites, hydrogen sulphide (Rodriguez- Kabana, 1986). Oka and Yermiyahu (2002) reported that ammonia is more toxic to nematodes than ammonium ion (NH4+). Under acidic soil conditions, ammonia is ionized to $\mathrm{NH4+}$ (Oka et al. 2007). Moreover, an enhanced development of nematode competitors, antagonists and parasites on the feeding sub-strate provided by the compost was also suggested as a further mechanism of the RKN population decrease (RodríguezKábana et al., 1986). The poultry litter compost was also beneficial in suppressing nematode egg populations on cacao seedling roots. In a previous study, poultry litter or poultry litter compost, combined with specific crop rotations, suppressed $M$. incognita and Pratylenchus penetrans populations in microplots (Everts et al., 2006). This show the potential of composts adding to soil infested with nematodes, thereby decreasing nematode damage while allowing for the beneficial effects of the compost on the plants. The best results were achieved when composts applied at the high rate before nematode inoculation which resulted in reducing final nematode population by 78 to 
$84 \%$. These findings agree with those obtained by other researchers (Akhtar and Malik, 2000; Cayuela et al., 2008; Renčo et al., 2009). Compost tea contains soluble nutrients and beneficial microorganisms, including bacteria, fungi, protozoa, and nematodes (Szmidt and Dickson 2001 and Bahman et al.,2015). The organic materials act as carriers to these microorganisms and decomposition increased in the soil. Toxic gasses and compounds against nematodes formed, which in turn increased soil fertility and plant growth criteria (Chen et al., 2000). This could be attributed to those plant residues having a synergistic effect. The addition of organic compost and Nile fertile to biocides increased the activity and reproduction of the tested microorganisms and bio-control agents of soil borne pathogens when applied to soils in combination with organic materials reduced nematode (Chen et al., 2000, Radwan et al., 2004 and Youssef et al., 2008). Hassan, et al., (2010) found that the rice husk $(\mathrm{RH})$ and Sawdust (SD) were significantly reduced final populations/ $500 \mathrm{~cm}^{3}$ soil, nematode populations, number of galls, egg masses $/ 10 \mathrm{~g}$ of root and root galls indices of Meloidogyne spp. on tomato plant. Abou El-Atta, et al.,
(2012) showed that soil amended with rice hull compost and rice straw compost 10 days before transplanting un-significantly reduced population densities of $M$. incognita, galls, number of egg masses and eggs in eggplant root system compared with inoculated plants. Using of animal manures and town refuse as pre-planting or post planting treatments succeeded to improve plant growth criteria and diminish nematode parameters as well as achieved the high percentage increase values of nitrogen $(\mathrm{N})$, phosphorus $(\mathrm{P})$, potassium carbon $(C)$, and total phenol comparing to nematode alone.

\section{References}

Abd-Elgawad, M.M.M. (2014). Yield losses by phytonematodes: challenges and opportunities with special reference to Egypt. Egyptian Journal of Agronematology, 13(1):75-94.

Abd-Elgawad, M. M.M. (2021). Biological control of nematodes infecting eggplant in Egypt. Bulletin of the National Research Centre, 45(1): 1-9. Abou El-Atta, D.A. M., ; F. A. M. Mostafa and Taha, H.A. (2012). Effectiveness of Certain Botanical and City Waste Composts on Meloidogne Incognita Infecting Eggplant. Egyptian Journal of Agronematology, 11(1):90-105. 
Akhtar, M. and Malik, A. (2000). Roles of organic soil amendments and soil organisms in the biological control of plant-parasitic nematodes: A review. Bioresource Technology,74(1): 35-47.

Arancon, N. Q.; Galvis, P.; Edwards, C. and Yardim, E. (2003). The trophic diversity of nematode communities in soil treated with vermicompost. Pedobiologia, 47(5-6): 736 - 740.

Bahman, F.N.; Hatam, S.; Hasan, Al.; Gholam, Al. and Shahpesandi, S. (2015). An overview of the benefits of compost tea on plant and soil Structure. Society of Education, India, 6(1):154- 158

Bakr, R. A. (2017). Utilization of oleander leaves and fish waste on Root-knot nematode control. International journal of current Microbiology and applied sciences, 6 (2): 1912-1925.

Bakr, R. A.; Mahdy, M. E. and Mousa, E. M. (2011). A survey of root-knot and citrus nematodes in some new reclaimed lands in Egypt. Pakistan Journal of Nematology, 29(2): 165170.

Bakr, R.A.; M.E. Mahdy and E.M. Mousa (2020). Survey of root-knot nematodes Meloidogyne spp. associated with different economic crops and weeds in Egypt. Egyptian Journal of Crop Protection, 15(2): 114.
Bakr, R.A. and Ketta, H.A. (2018).

Nematicidal potential of some botanical products against Meloidogyne incognita infecting Eggplant. Indian Journal of Nematology, 48 (2):203-211.

Barker, K. R. (1985). Nematode extraction and bioassays. In: Gads, K. R. Barker, C. C. carter and J. N. Sasser, eds, An Advanced Treotise on Meloidogyne, North Caroline State Univ., 11: 19-38.

Broesh, S. (1954). Colorimetric assay of phenoloxidase. Bull. Sac. Chem. Biol., 36: 711 - 713.

Castillo, P.; Navas-Cortés, J. A.; Gomar-Tinoco, D.; Di Vito, M. and Jiménez-Díaz, R. M. (2003). Interactions between Meloidogyne artiellia, the cereal and legume rootknot nematodes and Fusarium oxisporum f.sp. ciceris race 5 in chickpea.

Phytopathology, 93(12):1513-1523.

Cayuela, M.L.; Millner, P.D.; Meyer, S.L. and Roig A. (2008). Potential of olive mill waste and compost as biobased pesticides against weeds, fungi and nematodes. Science of The Total Environment, 399(1-3): 11 $-18$.

Chen, J.; Abowi, G. S. and Zuckerman, B. M. (2000). Efficacy of Bacillus thuringiensis, Paecilomyces 
marquandi, and Streptomyces costaricanus with and without organic amendments against Meloidogyne hapla infecting lettuce. Journal of Nematology, 32 (1): 7077.

D'Addabbo, T. and Sasanelli, N. (1997). Suppression of Meloidogyne incognita by combination of olive pomace or wheat straw with urea. Nematologia Mediterranea, 25: 159 164.

D’Addabbo, T.; Papajová, I.; Sasanelli, N.; Radicci, V. and Renčo, M. (2011). Suppression of root-knot nematodes in potting mixes amended with different composted biowastes. Helminthologia, 48(4), 278.

Daykin, M. E. and Hussey, R. S. (1985). Staining and histopathological techniques in nematology. In: Barker, K. R.; C. C. carter and J. N. Sasser (eds), An advanced treatise on Meloidogyne, Vo. II Methodology, pp. 39 - 48.

Devi T.S.; Das D., Ansari R.A.; Rizvi R.; Sumbul A. and Mahmood I. (2020) Role of Organic Additives in the Sustainable Management of Phytoparasitic Nematodes. In: Ansari R.; Rizvi R.; Mahmood I. (eds) Management of Phytonematodes: Recent Advances and Future Challenges. Springer, Singapore.

Everts, K. L.; Sardanelli, S.; Kratochvil, R. J.; Armentrout, D. K. and Gallagher, L. E. (2006). Root-knot and root-lession nematode

suppression by cover crops, poultry litter, and poultry litter compost.

Plant Disease, 90 (4): 487-492.

FAO (2018). Food and Agriculture Organization of the United Nations. FAOSTAT database collections.

Fehrman, H. and Diamond A. E. (1967). Peroxidase activity and Phytophthora resistance in different organs of potato plant. Phytopathology, 57: 69-72.

Hassan, M. A.; Chindo, P. S.; Marley, P. S. and Alsgbej, M. D. (2010). Management of root-knot nematodes (Meloidogyne spp.) on tomato (Lycopersicon lycopersicum) using organic wastes in Zaria, Nigeria. Plant Protection Science,46 (1): 34-38.

Hussey, R. S. and Barker, K. R. (1973). A comparison of methods of collecting eggs of Meloidogyne spp., including a new technique. Plant Disease Reporter, 57:1025-1028. Ismail, A. E.; Rawia, A. E. and ElNagdi, W. M. A. (2006). Effect of different composts, biofertilizers and olive pomace as soil amendments 
on Rotylenchulus reniformis, growth and chemical analysis of jasmine Egypt. Journal of Applied Science Research, 2 (11): 909-916.

Kirmani, M. R.; Alam, M. M.; Khan, A. M. and Saxena, S. K. (1975). Effect of different carbon: nitrogen ratios on the population of nematodes and fungi and plant growth of cabbage. Indian Journal of Mycology and Plant Pathology, 5: 22-30.

Mahdy, M. E. (2002). Biological control of plant parasitic nematodes with antagonistic bacteria on different host plants. Ph.D. Thesis, Bonn University, Germany, pp.171.

Manzanilla-Lopez, R.H.E.K. and J. Bridge. (2004). Plant diseases caused by nematodes. CABI Publish. Beijing, China.

Mian, I. H. and Rodriguez-Kabana, R. (1982). Organic amendments with high tannin and phenolic contents for control of Meloidogyne arenaria in infested soil. Nematropica, 12:221- 234 .

Nahar, M. S.; Grewal, P. S.; Miller, S. A.; Stinner, D.; Stinner, B. R.; Kleinhenz, M. D. and Doohan, D. (2006). Differential effects of raw and composted manure on nematode community, and its indicative value for soil microbial, physical and chemical properties.
Applied Soil Ecology,34(2-3): 140 151.

Norton, D. C. (1978). Ecology of plant parasitic nematode. John Willey and Sons. New York, p. 238.

Oka Y.; Tkachi N.; Shuker S. and Yermiyahu U. (2007). Enhanced nematicidal activity of organic and inorganic ammonia-releasing amendments by Azadirachta indica extracts. Journal of Nematology, 39:9-16.

Oka, Y. and Yermiyahun, U. (2002). Suppressive effects of composts against the root-knot nematode Meloidogyne javanica on tomato. Nematology, 4(8): 891-898.

Radwan, M. A.; Abu-Elamayem, M. M.; Kassem, S. M. and El-Maadawy, E. K. (2004). Management of Meloidogyne incognita root-knot nematode by integration with either organic amendments or carbofuran. Pakistan Journal of Nematology, 22 (2): 135-142.

Renčo, M.; D'Addabbo, T.; Sasanelli, N. and Papajová, I. (2007). The effect of five compost of different origin on the survival and reproduction of Globodera rostochiensis. Nematology, 9(4): 537 $-543$.

Renčo, M.; Sasanelli, N. and Kováčik, P. (2011). The effect of soil compost 
treatments on potato cyst Sikora, R.A. and Fernandez, E. (2005).

nematodes Globodera rostochiensis and Globodera pallida. Nematode parasites of vegetables.

Helminthologia, 48 (3): 184-194.

Renco, M.; Sasanelli, N. and Salamun, P. (2009). The effect of two compost soil amendments, based on municipal green and penicillin production wastes, on plant parasitic nematodes. Helminthologia, 46 (3): 190-197.

Rodriguez-Kabana, R. (1986). Organic and inorganic nitrogen amendments to soil as nematode suppressants. Journal of Nematology,18(2):129135.

Rodriguez-Kabana, R.; Estaun, V.; Pinochet, J. and Marfa, O. (1995). Mixtures of olive pomace with different nitrogen sources for the control of Meloidogyne spp. on tomato. Journal of Nematology, 27(4S): 575 - 584.

Sasser, J. N. and Freckman, D. w. (1987). A world perspective on Nematology: the role of the society.In: Vistas on Nematolog. eds. By J.A. Veech and D.W. Dickson. Pp: 7-14 in Society of Nematologists. Hyattsville, Maryland. In: Plant-Parasitic nematodes in subtropical and tropical agriculture. in: M. Luc, R.A. Sikora and J. Bridge. eds. Pp: 319-392. CABI Publishing, Wallingford. UK.

Szmidt, R.A.K. and Dickson, A.W. (2001). Use of compost in agriculture. Scottish Agricultural College.

Wuest, P. J.; Levanon, D. and Hadar, Y. (1995). Environmental, agricultural and industrial uses for spent mushroom substrate from mushroom farms. Emmaus: JG Press, Inc, 511, 512-513.

Youssef, M. M. A.; El-Nagdi, W. M. A. and Abd El-Fattah, A. I. (2008). Efficacy of chicken compost, Bacillus thuringiensis and Pseudomonas fluorescens for biocontrolling Meloidogyne incognita infecting sugar beet. International Journal of Nematology. 18 (1): 3540.

Received: January 30, 2021.

Revised: March20, 2021.

Accepted: April 10, 2021.

How to cite this article:

Al-Hendy, M.; R.A. Bakr; M.E. Mahdy and E.M. Mousa (2021). Ecofriendly management of rootknot nematodes on eggplant using compost. Egyptian Journal of Crop Protection, 16(1): 1-19. 